\title{
PENGOLAHAN AIR LIMBAH PEWARNA SINTETIS DENGAN METODE ADSORPSI DAN ULTRAVIOLET
}

\author{
Nurlela \\ Dosen Tetap Program Studi Teknik Kimia \\ Universitas PGRI Palembang \\ e-mail:Lela_dj79@yahoo.co.id
}

\begin{abstract}
ABSTRAK
Pengolahan air limbah merupakan salah satu teknik untuk menurunkan tingkat pencemaran dan bahaya air limbah bagi lingkungan dan manusia. Air limbah bahan pewarna tersebut juga dapat mematikan organisme yang hidup di lingkungan. Salah satu alternatif penanganan air limbah sintetis adalah dengan cara adsorpsi. Pada penelitian ini air limbah sintetis dibuat sendiri dari pewarna procion biru, dengan konsentrasi masing-masing pewarna adalah $500 \mathrm{mg} / \mathrm{l}, 750 \mathrm{mg} / \mathrm{l}$ dan $1000 \mathrm{mg} / \mathrm{l}$. Tujuan dari penelitian ini adalah untuk mengetahui pengaruh konsentrasi air limbah pewarna sintetis dan jenis adsorben yang digunakan, serta untuk mecari penanganan air limbah adsorben yang digunakan, serta untuk mecari penanganan air limbah sintetis adalah dengan cara adsorpsi. . Proses adsorpsi dilakukan dengan memvariasikan adsorben berupa karbon aktif dan zeolit. Berdasarkan hasil riset karbon aktif lebih efektif dibandingkan zeolit. sehingga karbon aktif dilanjutkan untuk proses ultraviolet.
\end{abstract}

Kata kunci : karbon aktif, adsorpsi, air limbah sintetis, procion biru

\section{PENDAHULUAN}

Limbah cair industri batik memiliki intensitas warna yang sangat tinggi sehingga jika air limbah itu langsung dibuang ke badan air akan merusak estetika badan air penerima dan badan air yang bewarna pekat akan menyebabkan tembusnya sinar matahari akan berkurang yang menyebabkan kehidupan air terancam dan apabila zat warna yang digunakan mengandung logam berat maka biota air akan teracuni. Selain air limbah industri batik bersifat racun dan karsinogen (Agustina, T.E. dan Badewasta, H. 2009).

Teknologi pengolahan air limbah merupakan salah satu teknik untuk menurunkan tingkat pencemaran dan bahaya dari air limbah bagi lingkungan dan manusia. Terdapat beragam teknologi pengolahan air limbah yang dapat diterapkan namun perlu dipertimbangkan beberapa hal yaitu: harus dapat dioperasikan dan dipelihara oleh pihak industri, dapat menurunkan pencemaran dalam air limbah ke tingkat yang sesuai atau lebih rendah dari baku mutu yang ditetapkan, layak secara ekonomi dalam pembangunan (konstruksi), operasional dan pemeliharaannya

Beberapa penelitian telah dilakukan dalam mengolah limbah industri batik dengan cara kimia, fisika, biologi atau kombinasi dari dua atau ketiganya. (Soedarsono (2007), dalam Badewasta (2010)) telah melakukan studi mengenai pengolahan air limbah batik dengan proses kombinasi elektrokimia, filtrasi, dan adsorpsi dengan menggunakan pasir silika dan arang aktif. Dari penelitian tersebut dari hasil analisa sampel limbah yang telah diolah didapatkan penurunan warna sebesar 99,25\% dengan menggunakan karbon aktif setebal $20 \mathrm{~cm}$. Kemampuan karbon aktif dalam mengolah limbah zat warna juga teruji dalam penelitian yang dilakukan oleh Masriati (2006) dan Juniar (2008). Disamping itu Badewasta (2010) telah melakukan studi mengenai pengolahan limbah batik dengan menggunakan filtrasi dan adsorpsi dengan menggunakan pasir dan zeolit sebagai filter dan adsorben. 
Dalam penelitian ini limbah batik akan diolah dengan menggunakan Proses Adsorpsi yaitu karbon aktif dan zeolit serta mengkombinasikannya dengan ultra violet.

\section{TINJAUAN PUSTAKA}

\section{Adsorpsi Fisika dan Kimia}

Adsorpsi (penyerapan) adalah suatu peristiwa perubahan konsentrasi yang terjadi pada bidang batas antara dua fase, karena zat dari fase yang satu melekat pada fase yang lain (terjadi pada permukaan). Sedangkan fase penyerap (adsorbing fase) yang berfungsi mengasorpsi disebut adsorben dan zat yang terkonsentrasi atau teradsorpsi pada permukaan fase lain disebut adsorbat. Proses adsorpsi dapat digambarkan sebagai proses dimana molekul meninggalkan larutan dan menempel pada permukaan zat adsorben akibat kimia dan fisika (Reynolds, 1982).

Peristiwa adsorpsi dapat terjadi bila dua fase bergabung sehingga terjadi suatu proses dimana molekul dari satu fase melekat pada permukaan fase yang lain. Kedua fase ini dapat berupa fase cair dengan fase cair, fase cair dengan fase gas, fase cair dengan fase padat dan fase gas dengan fase padat. Peristiwa adsorpsi berguna untuk memisahkan suatu senyawa atau zat dari systim fisika, kimia dan biologi dari satu fase yang diikuti oleh akumulasi atau pengkonsentrasian pada permukaan fase lainnya (fase padat). Biasanya partikel-partikel fase padat ditempatkan pada suatu tempat (hamparan)dan cairan yang akan diadsorpsi dialirka atau dicampur dengan fase padat sehingga terjadi proses adsorpsi sampai fase padat tersebut mendekati atau menjadi jenuh.

Faktor-faktor yang mempengaruhi proses adsorpsi, yaitu:

- Sifat fisik dan kimia dari adsorben seperti luas permukaan, ukuran pori dan komposisi kimia.

- Sifat fisik dan kimia fase terserap, seperti ukuran molekul, polaritas molekul dan komposisi kimia.

Adsorben yang telah lama dikenal dan sering digunakan pada industri antara lain arang aktf, silika gel, alumina, polimer berpori dan mineral. Pemilihan adsorben akan mempengaruhi kapasitas adsorpsi antara lain:

- Luas permukaan, semakin halus partikel adsorben, semakin luas permukaan adsorben semakin banyak adsorbat yang dapat diserap sehingga akan mempermudah dan mempercepat proses adsorpsi. Semakin kecil ukuran diameter partikel maka semakin luas permukaan adsorben.

- Ukuran pori, kebanyakan zat pengasorpsi (adsorben) adalah bahan-bahan yang sangat berpori dan adsorpsi akan berlangsung pada dinding-dinding pori atau pada bagian tertentu di dalam partikel adsorben.

- Waktu kontak merupakan suatu hal yang sangat menentukan dalam proses adsorpsi. Waktu kontak yang lebih lama memungkinkan proses difusi dan penempelan molekul adsorbat berlangsung lebih baik. Konsentrasi zat-zat organik akan turun apabila waktu kontaknya cukup dan waktu kontak berkisar 10 - 15 menit (Reynold, 1982).

\section{Manfaat Karbon Aktif}

Pemanfaatan karbon aktif antara lain untuk mengatasi masalah lingkungan (penanganan limbah), pemurnian gas, pemanfaatan dalam bidang medis dan lain-lain. Karbon aktif juga dapat digunakan sebagai katalis dalam pembuatan asam sulfat dari larutan belerang dioksida. Dalam hal ini karbon aktif berfungsi sebagai pengadsorpsi belerang dioksida dari larutan aquousnya, kemudian dioksidasi lebih lanjut di permukaan karbon aktif menjadi belerang tioksida dan dengan adanya molekul air terjadi reaksi pembentukan asam sulfat yang kemudian lepas dari permukaan karbon aktif (Juniar, 2008) 
Kemampuan karbon aktif dalam mengolah limbah zat warna juga teruji dalam penelitian yang dilakukan oleh Masriatini (2006)

Pemanfaatan karbon aktif antara lain sebagai berikut:

a. Dalam pemurnian gas yang digunakan untuk desulfurisasi yaitu menghilangkan gas beracun, bau busuk, asap dan pencegahan racun.

b. Dalam pengolahan LNG digunakan dalam proses desulfurisasi.

c. Digunakan sebagai katalis atau pengemban dalam berbagai reaksi misalnya mengkatalisasi pembentukan sulfur klorida dari sulfur dioksida dan klorin, sebagai pengemban dalam reaksi. Karbon aktif juga sebagai promotor yang mempengaruhi laju reaksi.

d. Dalam industri obat dan makanan digunakan sebagai bahan penyaring dan penghilang warna, bau serta rasa yang tidak dikehendaki.

e. Dalam industri minuman keras dan ringan digunakan untuk menghilangkan bau dan warna.

f. Dalam budi daya udang dan benur berguna untuk pemurnian air, menghilangkan amonia, nitrit, fenol dan logam berat.

g. Dalam kimia perminyakan digunakan dalam penyaringan bahan mentah atau zat udara.

h. Dalam pengolahan air bermanfaat untuk menghilangkan atau menyaring zat bau, zat warna dan bahan pencemar.

i. Di bidang penyaringan minyak, makanan dan glukosa, untuk menghilangkan zat bau, warna serta rasa yang tidak dikehendaki.

\section{Zeolit}

Zeolit baru dikenal sebagai bahan tambang setelah ditemukan pada tahun 1756 oleh B.A.F Cronsted seorang ahli mineral dari Swedia. Namun Zeolit berasal dari dua kata Yunanim zeo artinya mendidih dan lithos artinya batuan. Zeolit (Zeinlithos) atau berarti juga batuan mendidih, di dalam riset-riset kimiawan telah lama menjadi pusat perhatian. Para ahli meneralogi memperkirakan bahwa zeolit berasal dari muntahan gunung berapi yang membeku menjadi batuan vulkanik, sedimen, batuan metamorfose, dan selanjutnya melalui pelapukan karena pengaruh panas dan dingin yang terjadi dalam lubang-lubang dari batuan lava basal dan butiran halus dari batuan sedimen piroklastik. Setiap tahunnya, berbagai jurnal penelitian di seluruh dunia, selalu memuat pemanfaatan zeolit untuk berbagai aplikasi, terutama yang diarahkan pada aspek peningkatan efektifitas dan efisien proses industri dan pencemaran lingkungan.

Zeolit umumnya didefinisikan sebagai kristal alumina silika yang berstruktur tiga dimensi, yang tebentuk dari tetrahedral alumina dan silika dengan rongga-rongga di dalam yang berisis ion-ion logam, biasanya alkali atau alkali tanah dan molekul air yang dapat bergerak bebas. Secara empiris, rumus molekul zeolit adalah $\mathrm{M}_{\mathrm{x} / \mathrm{n} .}\left(\mathrm{AlO}_{2}\right)_{\mathrm{x} .}\left(\mathrm{SiO}_{2}\right)_{\mathrm{y} . \mathrm{x}} \mathrm{H}_{2} \mathrm{O}$. Struktur zeolit sejumlah ini diketahui bermacam-macam, tetapi secara garis besar strukturnya terbentuk dari unit bangun polimer, berupa tetrahedral yang kemudian menjadi unit struktur zeolit. Struktur zeolit yang berpori dengan molekul air didalamnya, melalui pemanasan menyebabkan molekul air mudah lepas sehingga menjadi zeolit spesifik sebagai adsorben, penukar ion dan katalisator. Adapun Sifat-Sifat Zeolit meliputi:

\section{a. Dehidrasi}

Sifat dehidrasi dari zeolit akan berpengaruh terhadap sifat-sifat adsorpsinya, zeolit dapat melepaskan molekul air dari rongga permukaan dan menyebabkan medan listrik meluas ke dalam rongga utamadan akan efektif terinteraksi dengan molekul yang akan di adsorpsi. Jumlah molekul air sesuai dengan jumlah pori-pori atau volume ruang hampa yang akan terbentuk bila kristal zeolit tersebut dipanaskan. 


\section{b. Adsorpsi}

Dalam keadaan normal ruang hampa kristal zeolit terisi oleh molekul air bebas yang berada disekitar kation. Bila kristal zeolit dipanaskan pada suhu $300-400^{\circ} \mathrm{C}$ maka ion tersebut akan keluar sehingga zeolit dapat berfungsi sebagai penyerap gas atau cairan. Beberapa jenis mineral zeolit mampu menyerap gas atau zat, zeolit juga mampu memisahkan molekul zat berdasarkan ukuran kepolarannya.

\section{c. Penukar ion}

Ion-ion pada rongga atau kerangka elektrolit berguna untuk menjaga kenetralan zeolit, ion-ion dapat bergerak bebas sehingga pertukaran ion menjadi tergantung dari ukuran dan muatan maupun jenis zeolitnya. Sifat sebagai penukar ion dari zeolit antara lain tergantung dari: sifat ation, suhu dan jenis anion. Penukar kation dapat menyebabkan perubahan beberapa sifat zeolit seperti terhadap panas, sifat adsorpsi dan sifat panas.

Ukuran peningkatan zeolit sebagai penyerap perlu terlebih dahulu dilakukan proses aktivasi, yaitu untuk meningkatkan sifat-sifat khusus zeolit dengan cara menghilangkan unsur-unsur pengotor dan menguapkan air yang terperangkap dalam pori kristal zeolit. Ada dua cara yang umum digunakan dalam proses aktivasi zeolit, yaitu pemanasan pada suhu $200-400{ }^{\circ} \mathrm{C}$ selama $2-3$ jam dan kimia dengan menggunakan pereaksi $\mathrm{NaOH}$ atau $\mathrm{H}_{2} \mathrm{SO}_{4}$

\section{Ultra Violet (UV)}

Sterilisator dengan ultra violet ini mempunyai keuntungan selain menyerap pembunuhan bakteri dapat berlangsung dalam waktu yang singkat. Selain itu desinfeksi dengan ultra violet ini tidak menghasilkan hasil samping sebagimana desinfeksi dengan menggunakan klorine.

Kelebihan reaktor ultraviolet

- Dapat merusak DNA sel, baik sel banteri, virus, jamur bahkan sel mamalia

- Efisien dan efektif tanpa efek samping yang berbahaya bagi lingkungan

- Dapat menurunkan COD,

\section{METODOLOGI PENELITIAN}

\section{Alat Penelitian:}

- Neraca analitik

- Beker gelas

- Gelas ukur

- Piper tetes

- Corong

- Kolom adsorpsi

- Bak Penampungan

\section{Bahan Penelitian}

- Air limbah batik cap khas Palembang

- karbon aktif

- zeolit

- Pewarna Procion Biru

- Aquades 


\section{Prosedur Penelitian}

Proses adsorpsi dilakukan dengan melewatkan air limbah pewarna sintetis dengan variasi konsentrasi $500 \mathrm{mg} / \mathrm{l}, 750 \mathrm{mg} / \mathrm{l}$ dan $1000 \mathrm{mg} / \mathrm{l} \mathrm{ke} \mathrm{dalam} \mathrm{kolom} \mathrm{adsorpsi} \mathrm{yang} \mathrm{diisi} \mathrm{adsorben} \mathrm{karbon}$ aktif atau zeolit dengan ketinggian $20 \mathrm{~cm}$.

Proses adsorpsi yang memberikan degradasi maksimal diterapkan untuk pengolahan air limbah hasil pencelupan batik cap khas Palembang. Analisa dilakukan untuk sampel awal sebelum adsorpsi dan juga analisa sampel hasil pengolahan setelah melalui kolom adsorpsi.

Air limbah pewarna sintetis kemudian dialirkan kedalam reaktor yang telah dilengkapi dengan lampu ultra violet selama 60 menit. Kemudian dianalisa

Proses adsorpsi yang memberikan degradasi maksimal diterapkan untuk pengolahan air limbah hasil pencelupan batik cap khas Palembang. Analisa dilakukan untuk sampel awal sebelum adsorpsi dan juga analisa sampel hasil pengolahan setelah melalui kolom adsorpsi dan Ultraviolet

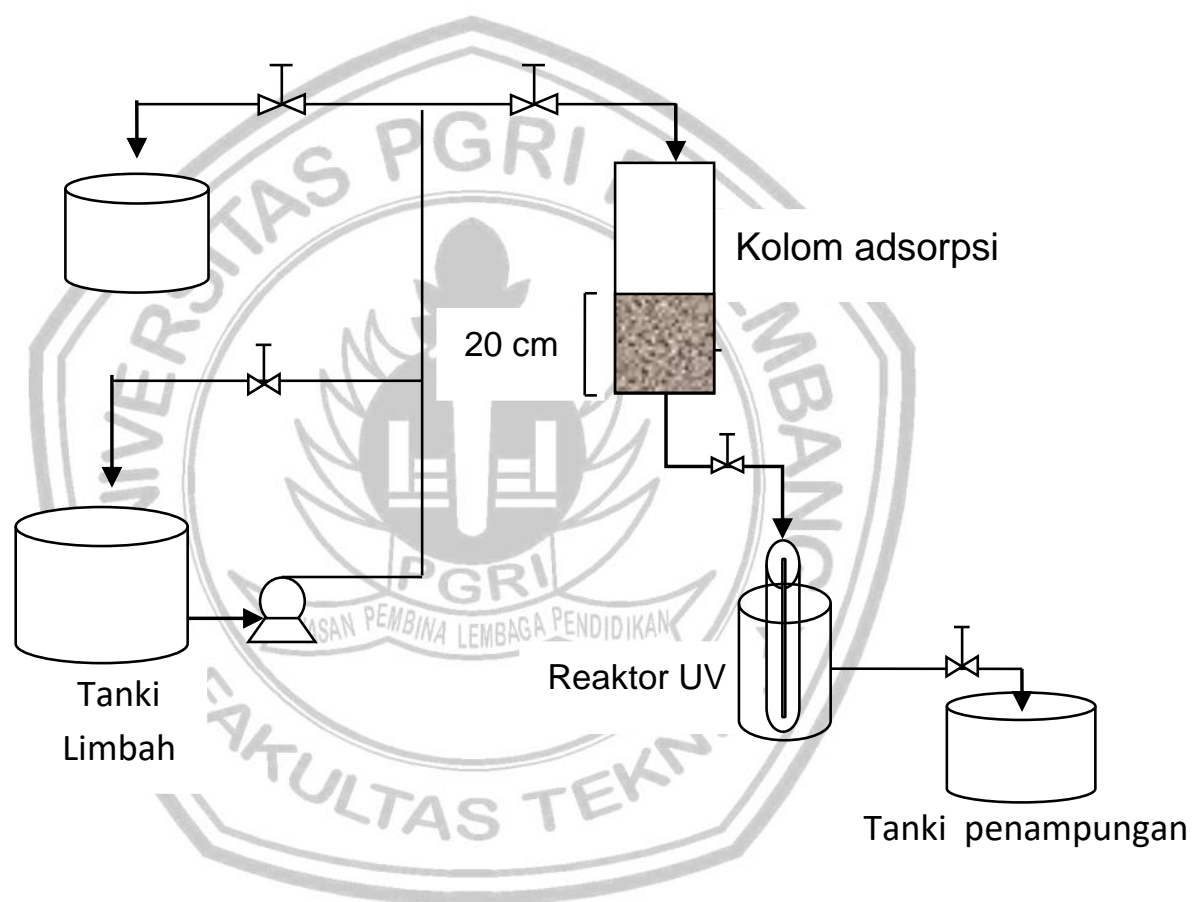

Gambar 1. Skema Alat Adsorpsi

\section{HASIL DAN PEMBAHASAN}

Pada penelitian pengolahan air limbah pewarna sintetis dengan metode adsorpsi dan ultraviolet ini, limbah yang dianalisa merupakan air limbah sintetis (buatan) dan air limbah hasil pencelupan batik cap khas Palembang. Pewarna sintetis yang digunakan yang digunakan adalah pewarna procion biru dengan konsentrasi $500 \mathrm{mg} / \mathrm{l}, 750 \mathrm{mg} / \mathrm{l}, 1000 \mathrm{mg} / \mathrm{l}$. Untuk proses adsorpsi digunakan karbon aktif dan zeolit. Selanjutnya adsorben yang memberikan persen penurunan terbesar dipilih. Selanjutnya dianalisa sampel hasil pengolahan setelah melalui kolom adsorpsi dan Ultra violet.

Analisa dilakukan pada saat sebelum adsorpsi dan sesudah adsorpsi dengan menggunakan karbon aktif karena karbon aktif memberikan persen penurunan COD, warna dan TSS yang lebih besat dibandingkan zeolit, maka hanya karbon aktif yang digunakan sebagai adsorben untuk pengolahan air limbah batik cap khas Palembang `lalu dilewatkan pada reaktor ultraviolet. Berikut adalah tabel hasil analisa awal yaitu saat sebelum adsorpsi dan analisa akhir yaitu saat setelah adsorpsi lalu setelah melewati reaktor ultraviolet: 
Tabel 1 Data Hasil Analisa Air Limbah Pencelupan Batik Cap Khas Palembang (Sebelum Adsorpsi Ultraviolet)

\begin{tabular}{|c|l|c|c|c|c|}
\hline $\begin{array}{c}\mathrm{N} \\
\mathrm{o}\end{array}$ & Parameter & Standar & $\begin{array}{c}\text { Sebelum } \\
\text { Adsorpsi }\end{array}$ & $\begin{array}{c}\text { Setelah } \\
\text { Adsorpsi }\end{array}$ & $\begin{array}{c}\% \\
\text { Penurunan }\end{array}$ \\
\hline 1. & $\mathrm{pH}$ & $6-9$ & 10,30 & 8,98 & 12,81 \\
2. & COD (mg/l) & 150 & 255 & 205 & 19,61 \\
3. & TSS (mg/l) & 50 & 80,2 & 54,2 & 32,42 \\
4. & Warna (ppm) & & 160,4 & 108,4 & 32,42 \\
5. & Chrom (mg/l) & 1 & 2,301 & 1,788 & 22,29 \\
\hline
\end{tabular}

Tabel 2. Data Hasil Analisa Air Limbah Pencelupan Batik Cap Khas Palembang (Setelah Adsorpsi Ultraviolet)

\begin{tabular}{|c|c|c|c|c|c|c|c|}
\hline No & Parameter & $\begin{array}{l}\text { Stand } \\
\text { ar }\end{array}$ & $\begin{array}{l}\text { Sebelum } \\
\text { Adsorpsi }\end{array}$ & $\begin{array}{c}\text { Setelah } \\
\text { Adsorpsi }\end{array}$ & $\begin{array}{c}\% \\
\text { Penurunan }\end{array}$ & $\begin{array}{c}\text { Setelah } \\
\text { Adsorpsi + } \\
\text { UV }\end{array}$ & $\begin{array}{c}\% \\
\text { Penurunan }\end{array}$ \\
\hline 1. & $\mathrm{pH}$ & $6-9$ & 10,30 & 8,98 & & 7,44 & 27,77 \\
\hline 2. & $\mathrm{COD}(\mathrm{mg} / \mathrm{l})$ & 150 & 255 & 205 & 19,61 & 142 & 44,31 \\
\hline 3. & TSS (mg/l) & 50 & 80,2 & 54,2 & 32,42 & 27,6 & 65,59 \\
\hline 4. & Warna (ppm) & & 160,4 & 108,4 & 32,42 & 35,2 & 78,05 \\
\hline 5. & Chrom (mg/l) & & 2,301 & 1,788 & 22,29 & 0,963 & 58,15 \\
\hline
\end{tabular}

Dari Tabel diatas dapat dilihat perbedaan saat sebelum adsorpsi dan setelah adsorpsi, begitu juga setelah adsorpsi dilanjutkan dengan proses ultra violet.Untuk nilai $\mathrm{pH}$ mengalami penurunan sebesar $12,81 \%$ dan setelah adsorpsi dilewatkan lagi melalui reaktor ultra violet sehingga $\mathrm{pH}$ mengalami penurunan kembali sebesar $27,77 \%$. Dimana $\mathrm{pH}$ mula-mula basa $(10,30)$ setelah proses adsorpsi $\mathrm{pH}$ menjadi mendekati normal yaitu 7,44. Untuk $\mathrm{pH}$ ini telah memenuhi baku mutu lingkungan yaitu nilai $\mathrm{pH}$ antara $6-9$.

Untuk nilai COD setelah adsorpsi juga mengalami penurunan dari $255 \mathrm{mg} / \mathrm{l} \mathrm{menjadi} 205 \mathrm{mg} / \mathrm{l}$ sebesar $19,61 \%$. Selanjutnya turun kembali setelah dilewatkan pada reaktor ultra violet menjadi 142 . Pada penurunan COD ini telah memenuhi baku mutu lingkungan yaitu sebesar $150 \mathrm{mg} / \mathrm{l}$.

Pada Nilai TSS juga mengalami penurunan dimana mula-mula $80,2 \mathrm{mg} / \mathrm{l}$ turun menjadi 54,2 $\mathrm{mg} / \mathrm{l}$ dan turun kembali menjadi $27,6 \mathrm{mg} / \mathrm{l}$ sehingga memenuhi baku mutu lingkungan yaitu dibawah $50 \mathrm{mg} / \mathrm{l}$.

Untuk kadar warna juga mengalami penurunan 160,4 ppm setelah dilakukan adsorpsi dengan karbon aktif menjadi 108,4 ppm, dan turun kembali menjadi 35,2 ppm setelah melalui reaktor ultra violet. Sebenarnya untuk wilayah sumatera selatan belum ada standar warna yang memenuhi baku mutu lingkungan tetapi dalam hal ini kami mengambil standar warna untuk DIY Yogyakarta yaitu sebesar 50 ppm. Sedangkan hasil setelah melalui reaktor ultra violet nilai warna sebesar 35,2 ppm jadi sudah memenuhi baku mutu lingkungan.

Penurunan logam chrom juga terjadi pada proses adsorpsi ini dimana kandungan logam chrom mula-mula 2,301mg/l turun menjadi $1,788 \mathrm{mg} / \mathrm{l}$ dan turun kembali menjadi $0,968 \mathrm{mg} / \mathrm{l}$ walaupun penurunannya sangat sedikit tetapi memenuhi baku mutu lingkungan yaitu $1 \mathrm{mg} / \mathrm{l}$

\section{KESIMPULAN}

1. Dari proses adsorpsi,semakin tinggi konsentrasi air limbah pewarna sintetis semakin kecil persen penurunan COD, warna dan TSS. Adsorben yang digunakan adalah karbon aktif dan zeolit, dengan 
melihat persen penurunan untuk COD, warna dan TSS maka karbon aktif lebih baik dibandingkan dengan zeolit.

2. Pada Proses adsorpsi dan ultra violet dengan melihat persen penurunan konsentrasi air limbah pewarna sintetis setelah melewati raktor ultra violet menunjukkan adanya peningkatan persentase penurunan

3. Pengolahan air limbah batik cap khas Palembang dengan menggunakan metode adsorpsi dan ultraviolet, didapat hasil akhir pengolahan limbah sudah memenuhi baku mutu lingkungan.

\section{DAFTAR PUSTAKA}

Agustina, T.E. dan Badewasta, H. (2009). Pengolahan limbah cair industri batik cap khas Palembang dengan proses filtrasi dan adsorpsi, Prosiding Seminar Nasional Teknik Kimia Indonesia 2009, Bandung 19-20 Oktober 2009

Badewasta,H.2010. "Pengaruh Ketinggian Unggun Pada Proses Filtrasi dan Adsorpsi Dalam Pengolahan Limbah Cair Industri Batik Dengan Pewarna Napthol di 5 Ulu Palembang". Tesis Magister Sains Program Pasca Sarjana Universitas Sriwijaya, Palembang

Juniar, H 2007. "Studi Pengaruh Tinggi Unggun Adsorben dan Debit Terhadap Penurunan Kualitas Limbah Cair Tenun Songket Tradisional Menggunakan Karbon Aktif Tempurung Kelapa". Tesis Program Magister Teknik Kimia Program Pasca Sarjana Universitas Sriwijaya, Palembang.

Masriati,R.2006. "Pengolahan Limbah Cair Industri Kerajinan Songket Tradisional Dengan Adsorpsi Menggunakan Karbon Aktif". Tesis Magister Teknik Program Pasca Sarjana Universitas Sriwijaya, Palembang

Reynolds, T.D. 1982. "Unit Operations and Process in Environmental Engineering”, Texas A \& M University, Books/Cole Engineering Division, Monterey, California, USA, pp 165 - 166. 